\title{
PERAN DAN PARTISIPASI ISTRI BURUH TANI DALAM UPAYA PENINGKATAN KESEJAHTERAAN KELUARGA
}

\author{
Ridayati $^{1)}$ dan Diah Suwarti $\mathrm{W}^{2)}$ \\ ${ }^{1}$ Program Studi Teknik Sipil STTNAS \\ ${ }^{2}$ Program Studi Teknik Elektro STTNAS \\ e-mail: ridayati@gmail.com
}

\begin{abstract}
ABSTRAK
Peran seorang ibu dalam membentuk sebuah rumah tangga yang sejahtera sangatlah besar karena ibu bertanggung jawab dalam mengatur rumah tangga dan pendidikan anak serta pengaturan biaya hidup keluarga. Pada keluarga yang perekonomiannya tergolong rendah seperti buruh tani, banyak kaum ibu yang menjadi penyelamat perekonomian rumah tangganya yaitu ikut mencari nafkah tambahan bagi keluarga karena penghasilan ayah sebagai pencari nafkah kurang mencukupi. Keterlibatan kaum perempuan di sektor publik selain di sektor domestik ini disebut peran ganda perempuan. Tulisan ini bertujuan untuk mengetahui peran istri buruh tani dalam meningkatkan ekonomi keluarganya di Kecamatan Minggir Kabupaten Sleman dan bentuk partisipasinya. Metode penelitian yang dipakai adalah Statistik Deskriptif Evaluatif untuk mendiskripsikan partisipasi buruh tani. Lebih lanjut, statistika deskriptif berupa perhitungan tabulasi silang (Cross Tabulation) digunakan untuk mengetahui peran istri buruh tani. Hasil Analisis menunjukkan bahwa meskipun peran istri buruh tani tidak mempengaruhi penghasilan suami, menurut uji Chi Kuadrat, namun Partisipasinya sangat besar dalam bentuk membantu suami dalam ikut bekerja di sektor publik.
\end{abstract}

Kata Kunci: Istri Buruh Tani, Peran Ganda, Kesejahteraan Keluarga

\begin{abstract}
The role of a mother in shaping prosperous households is very large because mother is responsible for the household and the education of children and family life costings. In families whose economies are relatively low as farm laborers, many of the mothers who became the savior of the household economy which join to seek additional income for the family because the father as breadwinner income insufficient. The involvement of women in the public sector in addition to the domestic sector is called the dual role of women. This paper aims to determine the role of a farm laborer's wife in raising their families in the District of Minggir Sleman region and forms of participation. The research method used is Descriptive Statistics to Describe the evaluative farm labor participation. Furthermore, statistics descriptive form of cross-tabulation calculation (Cross Tabulation) is used to determine the role of wife of a laborer. Analysis of the results showed that although the farm worker's wife's role does not affect the husband's income, according to the Chi-Squared test, but Engagement is very large in the form of helping her husband in the work on the public sector.
\end{abstract}

Keywords: Farm Laborer's Wife, Multiple Roles, Family Welfare

\section{PENDAHULUAN}

Keluarga adalah harta yang paling berharga. Keberhasilan seseorang dalam karier tidak akan dikatakan berhasil jika belum berhasil mensejahterakan keluarga kecilnya [1]. Hal ini berarti bahwa setinggi apapun karier seseorang tetap belum bisa dikatakan berhasil jika belum bisa membuat rumah tangganya tenteram, penuh kasih, damai, sejahtera, peduli pada sesama. Pada umumnya ayah sebagai subyek, kepala keluarga dan pencari nafkah, sedangkan kedudukan seorang ibu sebagai objek yang seakan-akan dinomorduakan karena ibu yang kebanyakan harus membimbing dan mendidik anak, mendampingi suami, mengatur pengeluaran biaya hidup keluarga, membantu mencari nafkah. Sehingga dapat dikatakan bahwa Peran seorang ibu dalam membentuk sebuah rumah tangga yang sejahtera sangatlah besar. Mario Teguh mengatakan "lebih mudah mencari uang yang sedikit (tugas ayah) dari pada mengelola uang yang sedikit (tugas ibu)”.

Notopuro berpendapat bahwa terdapat pembagian kerja antara ayah dan ibu, ayah memiliki areal pekerja publik karena kedudukannya sebagai pencari nafkah utama di dalam keluarga, sedangkan ibu memiliki areal pekerja domestik yang dapat diartikan oleh sebagian masyarakat yang menyatakan secara sinis bahwa seorang ibu hanya sekedar wanita 
yang memiliki tiga fungsi yaitu memasak, melahirkan anak, berhias, atau hanya memiliki tugas dapur, sumur, dan kasur [2]. Pada kenyataannya, banyak wanita yang tidak peduli konsep di atas. Banyak wanita yang berhasil dalam bisnisnya. Pada keluarga yang perekonomiannya tergolong rendah banyak kaum ibu yang menjadi penyelamat perekonomian rumah tangganya yaitu ikut mencari nafkah tambahan bagi keluarga karena penghasilan ayah sebagai pencari nafkah kurang mencukupi.

Salah satu contoh nyata adalah rumah tangga buruh tani yang sudah lama diketahui tergolong miskin. Istri buruh tani ternyata memiliki peranan yang sangat penting dalam menyiasati dan turut serta bekerja mencari nafkah untuk mengatasi kemiskinan yang dialaminya sebagai upaya meningkatkan kesejahteraan rumah tangganya disamping mengurus pekerjaan rumah. Keterlibatan wanita dalam sektor publik disamping sektor domestik ini disebut peran ganda [3].

Masyarakat Kecamatan Minggir Kabupaten Sleman adalah salah satu bukti nyata yang ada dalam masyarakat mengenai peran ganda perempuan pada masyarakat pedesaan sebagai kawasan pertanian. Keterlibatan istri buruh tani pada kegiatan ekonomi keluarga di Kecamatan Minggir memberikan pandangan tersendiri yaitu mereka tidak membakukan bahwa suami berperan di sektor publik sedangkan istri di sektor domestik. Mayoritas istri buruh tani di Kecamatan Minggir berpartisipasi langsung dalam hal mencari nafkah. Begitu pula suami kadang juga membantu istri mengasuh anak, mengajari anak belajar. Mereka telah terbiasa disosialisasi bagaimana menjadi istri petani yang baik. Bahkan istri buruh tani merasakan bahwa turut bekerja mencukupi kebutuhan rumah tangga adalah kewajiban meskipun mereka kadang merasakan ada yang tidak adil dalam hidup ini namun mereka tetap berjuang untuk masa depan anak-anaknya supaya nantinya dapat bekerja kantoran.

Berangkat dari latar belakang di atas, penulis tertarik mengangkat kehidupan istri buruh tani untuk mengetahui Peran dan partisipasi istri buruh tani dalam meningkatkan ekonomi keluarganya di Kecamatan Minggir.

\section{TINJAUAN PUSTAKA}

Peningkatan Peranan wanita dalam pembangunan telah secara khusus menjadi perhatian sejak GBHN 1978, dan dalam GBHN 1993 peran, partisipasi, dan status wanita dalam pembangunan telah mendapat tempat yang semakin mantap. Upaya peningkatan peranan wanita dalam Repelita VI diarahkan untuk mencapai kondisi kemitrasejajaran yang harmonis antara pria dan wanita dalam pembangunan dan kehidupan bermasyarakat, berbangsa dan bernegara, serta ikut melestarikan nilai-nilai Pancasila. Pembangunan yang dilaksanakan diberbagai bidang terutama pendidikan, ketenagakerjaan, kesehatan, kependudukan dan keluarga sejahtera telah berhasil meningkatkan kualitas wanita sehingga perannya dalam pembangunan lebih nyata.

Dalam rangka mencapai sasaran peningkatan peranan wanita dalam Repelita VI, ditempuh berbagai kebijaksanaan, yaitu: meningkatkan kualitas wanita sebagai sumber daya pembangunan; meningkatkan kualitas dan perlindungan tenaga kerja wanita; meningkatkan peran ganda wanita dalam keluarga dan masyarakat; mengembangkan iklim sosial budaya yang mendukung kemajuan wanita; serta membina kelembagaan dan organisasi wanita [4].

Perkembangan perempuan di berbagai belahan bumi memang menunjukkan bahwa partisipasi perempuan dalam keluarga, masyarakat dan negara ternyata tidak kalah penting dari laki-laki. Bukan hanya dalam aktifitas reproduksi dan domestik, perempuan juga mampu melakukan kegiatan di sektor publik yang menghasilkan uang untuk menambah pendapatan keluarga [5]. Sebenarnya keterlibatan perempuan sudah sejak jaman dulu, namun meskipun bukan fenomena baru perempuan bekerja masih terus menjadi perdebatan hingga saat ini [6]. Bagaimanapun juga masyarakat masih memandang bahwa keluarga yang ideal adalah suami bekerja pada sektor publik dan istri bekerja pada sektor domestik dengan berbagai pekerjaan rumah. 
Anggapan negatif yang kuat di masyarakat masih menganggap idealnya suami berperan sebagai pencari nafkah dan pemimpin yang penuh kasih, sedangkan istri menjalankan fungsi mengasuh anak. Hanya saja seiring perkembangan jaman peran-peran tersebut tidak semestinya dibakukan. Terlebih kondisi ekonomi yang membuat masyarakat menengah ke bawah tidak bisa menutup mata bahwa kadang-kadang istri dituntut untuk berperan ganda yaitu selain mengurus rumah tangga juga harus membantu bekerja di sektor publik. Hal ini terlihat jelas pada keluarga buruh tani dimana istri dituntut untuk berperan ganda.

Kesetaraan gender adalah kesamaan kondisi bagi laki-laki dan perempuan untuk memperoleh kesempatan serta hak-haknya sebagai manusia, agar mampu berperan dan berpartisipasi dalam kegiatan politik, hukum, ekonomi, sosial budaya, pendidikan dan pertahanan dan keamanan nasional (Hankamnas), serta kesamaan dalam menikmati hasil pembangunan tersebut. Terwujudnya kesetaran gender di masyarakat petani kecamatan minggir ditandai dengan tidak adanya diskriminasi antara perempuan dan lakilaki, dan dengan demikian mereka memiliki akses, kesempatan berpartisipasi dalam peningkatan kesejahteraan keluarga. Memiliki akses dan partisipasi berarti memiliki peluang atau kesempatan untuk menggunakan sumber daya dan memiliki wewenang untuk mengambil keputusan terhadap cara penggunaan dan hasil sumber daya tersebut [7].

\section{METODE PENELITIAN}

Metode penelitian yang dipakai adalah deskriptif evaluatif, yaitu metode penelitian yang mengevaluasi kondisi objektif apa adanya pada suatu keadaan yang menjadi obyek studi
[8]. Obyek studi yang dimaksud ibu rumah tangga yang mempunyai keluarga masih utuh dalam arti mempunyai suami yang syah dan anak. Disamping berperan sebagai istri (domestik) juga berperan sebagai pekerja di luar rumah tangganya. Tulisan ini memberikan gambaran tentang keadaan atau fenomena secara sistematis dan akurat mengenai faktafakta pada saat penelitian dilakukan (masalahmasalah yang bersifat aktual).

\section{HASIL DAN PEMBAHASAN}

Data pada tulisan ini diperoleh dari Kabupaten Sleman, Kecamatan Minggir dan 5 Kalurahan di Minggir yaitu Desa Sendangagung, Desa Sendangmulyo, Desa Sendangarum, Desa Sendangsari, dan Desa Sendangrejo. Data dari kabupaten berupa data Statistik Daerah Kabupaten Sleman. Data dari kecamatan adalah data Statistik Daerah Kecamatan Minggir dan Kecamatan Minggir dalam Angka, sedangkan dari Kalurahankalurahan adalah data monografi dan profil desa.

\section{Analisis Peran Ganda Istri Buruh Tani}

Keluarga Buruh tani merupakan keluarga miskin. Pada analisis ini, data banyaknya buruh tani diambil dari data keluarga miskin, dari data itu diperoleh pula data-data tentang banyaknya buruh tani yang dirinci perdesa, banyaknya buruh tani dan juga buruh serabutan, banyaknya istri buruh tani, banyaknya pelajar dari keluarga miskin. Namun karena buruh serabutan di Kecamatan Minggir juga merupakan buruh tani, maka buruh serabutan juga dihitung sebagai buruh tani yang ditunjukkan dalam Tabel 1 .

Hasil analisis dari banyaknya warga miskin se-Kecamatan Minggir (Tabel 1) menunjukkan bahwa pada tahun 2012 secara

Tabel 1. Banyaknya Buruh Tani dan Buruh Serabutan di Kecamatan Minggir 2012

\begin{tabular}{cccccc}
\hline No & Desa & $\begin{array}{c}\text { Jumlah Buruh } \\
(\text { Jiwa })\end{array}$ & $\begin{array}{c}\text { Jumlah Buruh } \\
\text { (KK) }\end{array}$ & $\begin{array}{c}\text { Jumlah Istri } \\
\text { Buruh (Jiwa) }\end{array}$ & $\begin{array}{c}\text { Jumlah Pelajar dari Keluarga } \\
\text { Miskin (Jiwa) }\end{array}$ \\
\hline 1 & Sendangsari & 417 & 271 & 179 & 209 \\
2 & Sendangrejo & 702 & 451 & 335 & 316 \\
3 & Sendangarum & 194 & 142 & 113 & 114 \\
4 & Sendangmulyo & 438 & 289 & 227 & 307 \\
5 & Sendangagung & 845 & 510 & 355 & 1380 \\
\hline \multicolumn{7}{l}{ Sumber : Hasil analisis tahun 2013} & 1663 & 1209 &
\end{tabular}


keseluruhan Jumlah buruh di Kecamatan Minggir ada 2595 jiwa yang terdiri dari 1663 KK. Jumlah buruh terbanyak terdapat di Desa Sendangagung yang mencapai 845 jiwa. Meskipun Luas tanam Desa Sendangagung lebih kecil dari Desa Sendangrejo, namun karena banyaknya buruh tani di Desa Sendangagung sehingga luas panen mencapai 437 hektar yang merupakan luas panen tertinggi dibanding desa-desa yang lain. Desa Sendangarum memiliki jumlah buruh yang paling rendah seiring dengan luas tanam yang paling sempit. Namun hal ini tidak menjadikan para buruh kecil hati, mereka mampu mencapai Luas tanam yang hampir sama dengan desadesa yang lain. Jumlah istri buruh tani di Kecamatan Minggir ada 1209 jiwa yang sangat bervariatif sekali dari segi usia maupun perilaku. Desa sendangagung mempunyai jumlah buruh yang paling banyak, sehingga di desa Sendangagung juga paling banyak istri buruh tani nya. Demikian juga untuk desa sendang arum yang kebanyakan penduduknya bekerja kantoran, sehingga jumlah buruh taninya lebih sedikit dibanding desa yang lain.

Jumlah pelajar dari keluarga miskin ada sebanyak 1380 jiwa, mereka adalah pelajar dari tingkat bawah (TK) sampai SMA, sedangkan yang meneruskan ke perguruan tinggi dari keluarga miskin sebanyak 8 orang.

Pada penelitian ini, pengambilan sampel terdiri dari 200 responden dengan rincian masing masing (5 desa) di kecamatan Minggir diambil 40 responden yang diperkirakan representative. Peneliti mengadakan pertemuan di masing-masing desa dengan bantuan kepala desa dan beberapa kepala dusun dengan mengundang 40 istri buruh tani di masing masing desa. Sebagian pengambilan data dilakukan di tempat responden bekerja, hal ini dikarenakan banyak faktor yang mempengaruhi sehingga sebagian responden yang diundang tidak semua hadir. Berikut dibahas tentang deskripsi hasil penelitian partisipasi istri buruh tani dalam upaya peningkatan kesejahteraan keluarga, peran istri buruh tani dalam upaya peningkatan kesejahteraan keluarga, partisipasi istri buruh tani dalam upaya peningkatan prestasi belajar anak, dan peran istri buruh tani dalam upaya peningkatan prestasi belajar anak.

\section{Deskripsi Hasil Penelitian Partisipasi Istri Buruh Tani dalam Upaya Peningkatan Kesejahteraan Keluarga}

Masyarakat Kecamatan Minggir merupakan masyarakat yang sebagian besar mata pencahariannya petani, hal ini dikarenakan lebih dari setengah luas lahan di kecamatan Minggir merupakan lahan sawah. Sehingga bagi yang tidak mempunyai lahan yang luas atau tidak mendapatkan pekerjaan yang lain, mereka mudah untuk mengambil keputusan bekerja sebagai buruh tani disamping tidak memerlukan pendidikan yang tinggi. Sebelum melakukan analisis, terlebih dahulu digambarkan secara umum identitas 200 responden.

Tabel 2 menunjukkan bahwa mayoritas responden berusia produktif, hal ini dapat dilihat pada masing masing desa rata-rata responden berusia kurang dari 50 tahun. Namun banyak juga yang sudah berusia di atas 50 tahun masih semangat dalam membantu suami mencari nafkah. Di Desa Sendangsari terdapat 5 responden yang berusia di atas 50 tahun, 7 responden dari Desa Sendangrejo, 6 dari Desa Sendangarum, 9 dari Desa Sendangagung, dan di Desa Sendangmulyo paling banyak yaitu ada 35\% atau 14 orang dari 40 responden. Kebanyakan Responden yang berusia di atas 50 tahun ditemui pada saat melakukan aktifitas rutin di sawah.

Berdasarkan Tabel 3, sebagian besar responden tamatan SMP dan SMA. Bahkan Responden di Desa Sendangarum yang berpendidikan SMA hampir setengahnya. Sebenarnya cukup berpendidikan, namun mereka tidak malu untuk turut bekerja membantu suaminya dalam mencari nafkah untuk mencukupi kebutuhan keluarganya meskipun harus turun ke sawah. Kebanyakan istri buruh tani yang lulus SMP atau SMA adalah mereka yang berusia produktif. Sedangkan untuk yang tamat SD maupun yang tidak sekolah adalah mereka yang usianya di atas 50 tahun. Hal ini dikarenakan pada jaman dahulu belum ada sekolah gratis, sedangkan mereka berasal dari keluarga kurang mampu, bisa makan pun sudah syukur.

Pada jaman sekarang ini mencari pekerjaan memang sulit, namun jika kita diam tidak berusaha maka tidak ada uang datang 
Tabel 2. Distribusi Usia Responden

\begin{tabular}{|c|c|c|c|c|c|c|c|c|}
\hline \multirow{3}{*}{$\begin{array}{r}\text { Desa } \\
\text { Sendangsari }\end{array}$} & \multicolumn{8}{|c|}{ Usia } \\
\hline & \multicolumn{2}{|c|}{$<30$ th } & \multicolumn{2}{|c|}{$30-40$ th } & \multicolumn{2}{|c|}{$40-50$ th } & \multicolumn{2}{|c|}{$>50$ th } \\
\hline & 6 & $15,0 \%$ & 17 & $42,5 \%$ & 12 & $30,0 \%$ & 5 & $12,5 \%$ \\
\hline Sendangrejo & 6 & $15,0 \%$ & 11 & $27,5 \%$ & 16 & $40,0 \%$ & 7 & $17,5 \%$ \\
\hline Sendangarum & 7 & $17,5 \%$ & 14 & $35,0 \%$ & 13 & $32,5 \%$ & 6 & $15,0 \%$ \\
\hline Sendangmulyo & 7 & $17,5 \%$ & 8 & $20,0 \%$ & 11 & $27,5 \%$ & 14 & $35,0 \%$ \\
\hline Sendangagung & 11 & $27,5 \%$ & 12 & $30,0 \%$ & 8 & $20,0 \%$ & 9 & $22,5 \%$ \\
\hline Jumlah & 37 & & 62 & & 60 & & 41 & \\
\hline
\end{tabular}

Tabel 3. Distribusi Pendidikan Terakhir Responden

\begin{tabular}{|c|c|c|c|c|c|c|c|c|}
\hline \multirow{2}{*}{ Desa } & \multicolumn{8}{|c|}{ Pendidikan Terakhir } \\
\hline & \multicolumn{2}{|c|}{ Tidak Sekolah } & \multicolumn{2}{|c|}{ SD } & \multicolumn{2}{|c|}{ SMP } & \multicolumn{2}{|c|}{ SMA } \\
\hline Sendangsari & 3 & $7,5 \%$ & 6 & $15,0 \%$ & 16 & $40,0 \%$ & 15 & $37,5 \%$ \\
\hline Sendangrejo & 5 & $12,5 \%$ & 7 & $17,5 \%$ & 14 & $35,0 \%$ & 14 & $35,0 \%$ \\
\hline Sendangarum & 4 & $10,0 \%$ & 7 & $17,5 \%$ & 11 & $27,5 \%$ & 18 & $45,0 \%$ \\
\hline Sendangmulyo & 5 & $12,5 \%$ & 7 & $17,5 \%$ & 13 & $32,5 \%$ & 15 & $37,5 \%$ \\
\hline Sendangagung & 2 & $5,0 \%$ & 5 & $12,5 \%$ & 19 & $47,5 \%$ & 14 & $35,0 \%$ \\
\hline Jumlah & 19 & & 32 & & 73 & & & \\
\hline
\end{tabular}

Tabel 4. Distribusi Pekerjaan Responden

\begin{tabular}{|c|c|c|c|c|c|c|c|c|c|c|}
\hline \multirow{3}{*}{$\begin{array}{r}\text { Desa } \\
\text { Sendanosari }\end{array}$} & \multicolumn{10}{|c|}{ Pekerjaan } \\
\hline & \multicolumn{2}{|c|}{ Bantu Suami } & \multicolumn{2}{|c|}{ Kerja Pabrik } & \multicolumn{2}{|c|}{ PRT } & \multicolumn{2}{|c|}{ Berdagang } & \multicolumn{2}{|c|}{ Serabutan } \\
\hline & 21 & $52,5 \%$ & 2 & $5,0 \%$ & 5 & $12,5 \%$ & 6 & $15,0 \%$ & 6 & $15,0 \%$ \\
\hline Sendangrejo & 18 & $45,0 \%$ & 2 & $5,0 \%$ & . & $20,0 \%$ & 6 & $15,0 \%$ & & $15,0 \%$ \\
\hline Sendangarum & 16 & $40,0 \%$ & 2 & $5,0 \%$ & 7 & $17,5 \%$ & 6 & $15,0 \%$ & 9 & $22,5 \%$ \\
\hline Sendangmulyo & 24 & $60,0 \%$ & 1 & $2,5 \%$ & 4 & $10,0 \%$ & 3 & $7,5 \%$ & 8 & $20,0 \%$ \\
\hline Sendangagı & 30 & $75,0 \%$ & 2 & $5,0 \%$ & 3 & $7,5 \%$ & 5 & $12,5 \%$ & 0 & $0,0 \%$ \\
\hline $\begin{array}{l}\text { Jumlah } \\
\end{array}$ & 109 & & 32 & & 27 & & 26 & & & \\
\hline
\end{tabular}

Tabel 5. Distribusi Pendapatan per Bulan Responden

\begin{tabular}{|c|c|c|c|c|c|c|c|c|}
\hline \multirow{3}{*}{$\begin{array}{c}\text { Desa } \\
\text { Sendangsari }\end{array}$} & \multicolumn{8}{|c|}{ Pendapatan Per Bulan Istri (Ribu Rupiah) } \\
\hline & \multicolumn{2}{|c|}{$<500$} & \multicolumn{2}{|c|}{$500-1.000$} & \multicolumn{2}{|c|}{$1.000-1.500$} & \multicolumn{2}{|c|}{$>1.500$} \\
\hline & 35 & $87,5 \%$ & 5 & $12,5 \%$ & 0 & $0,0 \%$ & 0 & $0,0 \%$ \\
\hline Sendangrejo & 36 & $90,0 \%$ & 4 & $10,0 \%$ & 0 & $0,0 \%$ & 0 & $0,0 \%$ \\
\hline Sendangarum & 37 & $92,5 \%$ & 3 & $7,5 \%$ & 0 & $0,0 \%$ & 0 & $0,0 \%$ \\
\hline Sendangmulyo & 39 & $97,5 \%$ & 1 & $2,5 \%$ & 0 & $0,0 \%$ & 0 & $0,0 \%$ \\
\hline Sendangagung & 38 & $95,0 \%$ & 2 & $5,0 \%$ & 0 & $0,0 \%$ & 0 & $0,0 \%$ \\
\hline Jumlah & 185 & & 15 & & 0 & & 0 & \\
\hline
\end{tabular}

begitu saja. Sebagai Istri buruh tani yang penghasilannya tidak menentu, mau tak mau para istri buruh tani ini harus ikut berperan dalam mencukupi kebutuhannya. Sebagian besar istri buruh tani hanya membantu pekerjaan suaminya di sawah, mengolah sawah majikannya. Dari 200 responden hanya ada 9 orang yang bekerja di pabrik-pabrik (bagian Produksi) yang jaraknya tidak jauh dari Minggir, Seperti pabrik kaos tangan dijalan Godean, pabrik GKBI, pabrik Plastik, dan lainlain di Sleman, Pabrik Kecap di Jombor, Pabrik Gula "Madukismo" di Bantul. Ada sebanyak 27 responden yang bekerja sebagai Pembantu rumah tangga, 26 orang berdagang dan 29 orang bekerja serabutan. Bekerja serabutan adalah mereka jika disuruh oleh tetangganya misalnya menyetrika, jemput anaknya sekolah, mencuci, memasak jika ada yang punya gawe.

Istri buruh tani berpartisipasi aktif dalam upaya peningkatan kesejahteraan keluarga dengan membantu suaminya bekerja di sawah. Walaupun tidak dapat dinilai dengan rupiah, namun kegiatan para istri buruh tani ini sangat meringankan beban kepala rumah tangga. Bahkan jika dirupiahkan, tidak ada Rp 500.000,- per bulannya. Para istri buruh tani yang berpenghasilan antara Rp 500.000,- 
Tabel 6. Distribusi per Bulan Suami Responden

\begin{tabular}{lrlcccccc}
\hline \multirow{2}{*}{ Desa } & \multicolumn{7}{c}{ Pendapatan per Bulan Istri (Ribu Rupiah) } \\
\cline { 2 - 9 } & \multicolumn{2}{c}{$<00$} & $500-1.000$ & $1.000-1.500$ & $>1.500$ \\
\hline Sendangsari & 17 & $42.5 \%$ & 23 & $57.5 \%$ & 0 & $0.0 \%$ & 0 & $0.0 \%$ \\
Sendangrejo & 28 & $70.0 \%$ & 12 & $30.0 \%$ & 0 & $0.0 \%$ & 0 & $0.0 \%$ \\
Sendangarum & 25 & $62.5 \%$ & 15 & $37.5 \%$ & 0 & $0.0 \%$ & 0 & $0.0 \%$ \\
Sendangmulyo & 25 & $62.5 \%$ & 15 & $37.5 \%$ & 0 & $0.0 \%$ & 0 & $0.0 \%$ \\
Sendangagung & 9 & $22.5 \%$ & 31 & $77.5 \%$ & 0 & $0.0 \%$ & 0 & $0.0 \%$ \\
\hline Jumlah & 104 & \multicolumn{10}{c}{96} & 0 & & 0 & \\
\hline
\end{tabular}

Tabel 7. Distribusi Alasan Suami Kerja Sebagai Buruh Tani

\begin{tabular}{lrrrrrrrr}
\hline \multirow{2}{*}{ Desa } & \multicolumn{6}{c}{ Alasan Bekerja sebagai Buruh Tani } \\
\cline { 2 - 9 } & \multicolumn{2}{c}{ Kebutuhan } & \multicolumn{2}{c}{$\begin{array}{c}\text { Dipercaya } \\
\text { Majikan }\end{array}$} & \multicolumn{2}{c}{ Mudah } & \multicolumn{1}{c}{$\begin{array}{c}\text { Tidak Ada } \\
\text { Pekerjaan Lain }\end{array}$} \\
\hline Sendangsari & 27 & $67,5 \%$ & 2 & $5,0 \%$ & 6 & $15,0 \%$ & 5 & $12,5 \%$ \\
Sendangrejo & 27 & $67,5 \%$ & 2 & $5,0 \%$ & 6 & $15,0 \%$ & 5 & $12,5 \%$ \\
Sendangarum & 29 & $72,5 \%$ & 0 & $0,0 \%$ & 3 & $7,5 \%$ & 8 & $20,0 \%$ \\
Sendangmulyo & 29 & $72,5 \%$ & 0 & $0,0 \%$ & 3 & $7,5 \%$ & 8 & $20,0 \%$ \\
Sendangagung & 25 & $62,5 \%$ & 4 & $10,0 \%$ & 6 & $15,0 \%$ & 5 & $12,5 \%$ \\
\hline Jumlah & 137 & & 8 & & 24 & & 31 & \\
\hline
\end{tabular}

Tabel 8. Distribusi Lama Responden Bekerja per Hari

\begin{tabular}{|c|c|c|c|c|c|c|c|c|}
\hline \multirow{2}{*}{ Desa } & \multicolumn{8}{|c|}{ Lama Bekerja per Hari } \\
\hline & \multicolumn{2}{|c|}{$<6 \mathrm{Jam}$} & \multicolumn{2}{|c|}{$8 \mathrm{Jam}$} & \multicolumn{2}{|c|}{$8 \mathrm{Jam}$} & \multicolumn{2}{|c|}{$>8 \mathrm{Jam}$} \\
\hline Sendangsari & 26 & $65,5 \%$ & 8 & $20,0 \%$ & 6 & $15,0 \%$ & 0 & $0,0 \%$ \\
\hline Sendangrejo & 23 & $57,5 \%$ & 11 & $27,5 \%$ & 6 & $15,0 \%$ & 0 & $0,0 \%$ \\
\hline Sendangarum & 22 & $55,0 \%$ & 10 & $25,0 \%$ & 8 & $20,0 \%$ & 0 & $0,0 \%$ \\
\hline Sendangmulyo & 23 & $57,5 \%$ & 7 & $17,5 \%$ & 10 & $25,0 \%$ & 0 & $0,0 \%$ \\
\hline Sendangagung & 22 & $55,5 \%$ & 10 & $25,5 \%$ & 8 & $20,0 \%$ & 0 & $0,0 \%$ \\
\hline Jumlah & 116 & & 46 & & 38 & & 0 & \\
\hline
\end{tabular}

sampai dengan Rp 1.000.000,- adalah mereka yang bekerja di pabrik dan atau pedagang, baik sebagai pedagang keliling maupun menetap. Dari 200 responden tidak ada yang berpenghasilan di atas $\mathrm{Rp} 1.000 .000$,- per bulan.

Pendapatan Buruh tani per bulan sebenarnya tidak menentu, mereka mendapatkan upah setiap panen yaitu setiap 3 bulan sekali atau bahkan 4 bulan sekali. Itupun jika panennya bagus. Jika banyak hama, maka panen nya mungkin gagal, sehingga kebanyakan buruh tani berpenghasilan kurang dari Rp 500.000,--. Terdapat 94 responden yang mengaku penghasilan suaminya antara Rp 500.000,- sampai Rp 1.000.000,-. Pada penelitian ini tidak ada suami responden yang berpenghasilan di atas Rp 1.000.000,-. Saat-saat seperti ini, kaum istri harus pintar mengelola uang yang sedikit. Di desa Sendangagung, terlihat bahwa pendapatan suami lebih banyak dari pada penghasilan di desa-desa yang lain yaitu terdapat 31 responden dari 40. Hal ini dimungkinkan karena panen yang bagus.

Lahan sawah yang luas di Kecamatan Minggir merupakan kesempatan yang baik bagi mereka yang tidak berpendidikan tinggi dan tidak bekerja di kantor. Menjadi buruh tani adalah pekerjaan yang mudah dan bisa dilakukan oleh siapa saja asalkan mempunyai fisik yang sehat dan kuat. Biaya hidup yang semakin tinggi, memaksa seseorang harus mencari pekerjaan untuk memenuhi kebutuhan keluarganya. Tuntutan kebutuhan merupakan alasan tertinggi dari para responden. Alasan "Tidak ada pekerjaan yang lain" merupakan jawaban dari para responden yang suaminya masih muda dan sebenarnya ingin bekerja lebih mapan. Alasan "dipercaya oleh majikan" menempati urutan terendah. Hal ini karena banyak dari kalangan buruh tani yang mengolah sawah dengan majikan yang berganti-ganti.

Seorang istri buruh tani tidak bekerja di sawah seharian seperti sang suami, namun 
Tabel 9. Distribusi Jumlah Anak Responden

\begin{tabular}{|c|c|c|c|c|c|c|c|c|}
\hline \multirow{2}{*}{ Desa } & \multicolumn{8}{|c|}{ Jumlah Anak } \\
\hline & \multicolumn{2}{|c|}{0} & \multicolumn{2}{|c|}{1} & \multicolumn{2}{|c|}{2} & \multicolumn{2}{|c|}{3 atau Lebih } \\
\hline Sendangsari & 0 & $0,0 \%$ & 9 & $22,5 \%$ & 23 & $57,5 \%$ & 8 & $20,0 \%$ \\
\hline Sendangrejo & 0 & $0,0 \%$ & 11 & $27,5 \%$ & 22 & $55,0 \%$ & 7 & $17,5 \%$ \\
\hline Sendangarum & 0 & $0,0 \%$ & 7 & $17,5 \%$ & 28 & $70,0 \%$ & 5 & $12,5 \%$ \\
\hline Sendangmulyo & 0 & $0,0 \%$ & 6 & $15,0 \%$ & 21 & $52,5 \%$ & 13 & $32,5 \%$ \\
\hline Sendangagung & 0 & $0,0 \%$ & 10 & $25,0 \%$ & 19 & $47,5 \%$ & 11 & $27,5 \%$ \\
\hline Jumlah & 0 & & 43 & & 113 & & 44 & \\
\hline
\end{tabular}

Tabel 10. Distribusi Usia Anak Responden

\begin{tabular}{|c|c|c|c|c|c|c|c|c|}
\hline & \multicolumn{8}{|c|}{ Usia Anak } \\
\hline & \multicolumn{2}{|c|}{$0-5$ th } & \multicolumn{2}{|c|}{ 6-12th } & \multicolumn{2}{|c|}{ 13-17th } & \multicolumn{2}{|c|}{$>17$ th } \\
\hline Sendangsari & 15 & $37,5 \%$ & 11 & $27,5 \%$ & 14 & $35,0 \%$ & 0 & $0,0 \%$ \\
\hline Sendangrejo & 17 & $42,5 \%$ & 15 & $37,5 \%$ & 8 & $20,0 \%$ & 0 & $0,0 \%$ \\
\hline Sendangarum & 12 & $30,0 \%$ & 21 & $52,5 \%$ & 7 & $17,5 \%$ & 0 & $0,0 \%$ \\
\hline Sendangmulyo & 11 & $27,5 \%$ & 14 & $35,0 \%$ & 15 & $37,5 \%$ & 0 & $0,0 \%$ \\
\hline Sendangagung & 13 & $32,5 \%$ & 12 & $30,0 \%$ & 15 & $37,5 \%$ & 0 & $0,0 \%$ \\
\hline Jumlah & 68 & & 73 & & 59 & & 0 & \\
\hline
\end{tabular}

Tabel 11. Distribusi Pendidikan Anak Responden

\begin{tabular}{lrrrrrr}
\hline \multirow{2}{*}{ Desa } & \multicolumn{6}{c}{ Usia Anak } \\
\cline { 2 - 7 } & \multicolumn{2}{c}{ TK/SD } & \multicolumn{2}{c}{ SMP } & \multicolumn{2}{c}{ SMA/SMK } \\
\hline Sendangsari & 26 & $65,0 \%$ & 9 & $22,5 \%$ & 5 & $12,5 \%$ \\
Sendangrejo & 30 & $75,0 \%$ & 6 & $15,0 \%$ & 4 & $10,0 \%$ \\
Sendangarum & 30 & $75,0 \%$ & 3 & $7,5 \%$ & 7 & $17,5 \%$ \\
Sendangmulyo & 22 & $55,0 \%$ & 3 & $7,5 \%$ & 15 & $37,5 \%$ \\
Sendangagung & 22 & $55,0 \%$ & 3 & $7,5 \%$ & 15 & $37,5 \%$ \\
\hline Jumlah & 130 & & 24 & & 46 \\
\hline
\end{tabular}

mereka hanya sifatnya membantu sang suami. Istri buruh yang pekerjaannya hanya membantu suami di sawah kebanyakan bekerja kurang dari 6 jam. Istri yang bekerja sebagai Pembantu Rumah tangga, karyawan (Bagian Produksi) pabrik bekerja selama 8 jam sehari, namun kadang mereka harus lembur untuk menambah penghasilan mereka sehingga lama bekerja lebih dari 8 jam.

Anak adalah asset bagi setiap orang tua, demikian juga untuk kaum buruh yang menginginkan masa depan anaknya lebih baik dari pada orang tuanya. Buruh tani di kecamatan minggir kebanyakan mempunyai 2 anak. Hal ini menunjukkan bahwa pola keluarga kecil dan berencana sudah menjadi panutan dalam kehidupan berkeluarga responden. Terdapat 44 responden atau sekitar 25\% yang mengaku mempunyai anak lebih dari 2.

Banyak dari responden mempunyai anak yang sudah dewasa dan mempunyai anak sekolah. Sengaja kami mengambil sampel yang usia anak di bawah 17 tahun. Jika terdapat lebih dari 1 anak sekolah, kami meminta untuk memasukkan 1 saja anak sekolah yang paling kecil. Sebanyak 73 responden mempunyai anak berusia 6-12 tahun. Usia tersebut merupakan masa transisi, dimana anak menganggap dirinya cukup dewasa dan mampu mandiri. Maka dibutuhkan perhatian dan bimbingan responden yang mampu memantau pertumbuhan dan perkembangan anak.

Terdapat 46 responden mempunyai anak SMA/SMK, Banyak dari keluarga buruh tani yang menyekolahkan anak-anaknya di SMK dengan pertimbangan bahwa nanti setelah lulus bisa langsung bekerja dan tidak perlu meneruskan ke bangku perguruan tinggi karena faktor biaya yang tidak mencukupi. Dengan demikian dapat meringankan beban orangtuanya dengan membantu membiayai sekolah adik-adiknya.

Partisipasi istri buruh tani dalam upaya meningkatkan kesejahteraan keluarga di Kecamatan Minggir sangat besar dilihat dari usaha istri yang tidak tinggal diam melihat 
suami bekerja keras di sawah. Para istri buruh tani membantu pekerjaan suami di Sawah dan jam kerja per hari yang disediakan untuk membantu pekerjaan suami tidak sedikit.

\section{Peran Istri Buruh Tani dalam upaya Peningkatan Kesejahteraan Keluarga}

Perempuan istri buruh tani adalah sosok perempuan pedesaan baik yang dewasa maupun muda. Mereka adalah istri buruh tani yang terlibat secara langsung atau tidak dengan tetap atau sewaktu-waktu dalam kegiatan usaha tani dan kesibukan lainnya berhubungan dengan kehidupan dan penghidupan keluarga tani dipedesaan. Perempuan tani dari setiap daerah mempunyai masalah yang sama. Secara umum mereka menghadapi masalah yang sama pula. Yaitu tingkat hidup yang rendah, tingkat pendidikan dan kesempatan belajar kurang, pengetahuan dan keterampilan yang sangat terbatas dan tertinggal. Keadaan ini memaksa kaum istri harus ikut berperan meningkatkan kesejahteraan keluarga dengan bekerja meringankan beban suaminya dalam mencari nafkah. Kategori Penghasilan Istri dan Penghasilan Suami ditunjukkan dalam Tabel 12.

Peran istri buruh tani dalam upaya peningkatan kesejahteraan keluarga dilihat dari penghasilan istri vs penghasilan suami yang dianalisis menggunakan uji Chi Square dengan membandingkan nilai Fisher's Exact Test dengan nilai $\alpha=5 \%$, diperoleh kesimpulan bahwa di Desa Sendangsari, Sendangrejo, Sendangarum, Sendangmulyo Penghasilan Istri tidak berpengaruh terhadap Penghasilan Suami, sehingga variabel ini tidak layak untuk diuji lebih lanjut. Di Desa Sendangagung diperoleh nilai Fisher's Exact Test 0,046 sehingga diperoleh kesimpulan bahwa di Desa Sendangagung Penghasilan Istri berpengaruh terhadap Penghasilan Suami. Namun karena terdapat sell yang sama dengan nol pada sell cross tabulation, sehingga Odd rasionya tidak muncul, yang berarti tingkat keeratan hubungannya tidak dapat ditemukan atau nilai pengaruhnya kecil sekali. Hal ini dikarenakan banyaknya istri buruh tani yang hanya bekerja membantu suaminya di sawah atau kerja serabutan yang tidak tetap hasilnya.

\section{KESIMPULAN}

Kecamatan Minggir merupakan daerah pertanian, bahkan lebih dari setengah dari total luas lahan di kecamatan minggir (52,12 \%) merupakan lahan sawah yang ditanami padi, Mendong dan juga Tebu. Kecamatan Minggir menempati urutan ke 12 sebagai penghasil padi sawah terbanyak di Kabupaten Sleman. Selain itu, Kecamatan Minggir merupakan satusatunya penghasil mendong se-Kabupaten Sleman. Partisipasi Istri buruh tani dalam upaya meningkatkan kesejahteraan keluarga di Kecamatan Minggir sangat besar dilihat dari usaha istri yang tidak tinggal diam melihat suami bekerja keras di sawah. Para Istri buruh tani membantu pekerjaan suami di Sawah dan jam kerja per hari yang disediakan untuk membantu pekerjaan suami tidak sedikit. Peran istri buruh tani dalam upaya peningkatan kesejahteraan keluarga dilihat dari penghasilan istri vs penghasilan suami yang dianalisis menggunakan uji Chi Square ternyata memberikan hasil bahwa penghasilan istri tidak berpengaruh terhadap penghasilan suami, kecuali di Desa Sendangagung yang berpengaruh namun kecil sekali. Hal ini dikarenakan banyaknya istri buruh tani yang hanya bekerja membantu suaminya di sawah atau kerja serabutan yang tidak tetap hasilnya.

\section{DAFTAR PUSTAKA}

[1]. Mario Teguh Golden Ways, Metro TV.

Tabel 12. Kategori penghasilan Istri dan Penghasilan Suami 200 Responden

\begin{tabular}{lccccc}
\hline $\begin{array}{c}\text { Kategori penghasilan } \\
\text { Istri Suami }\end{array}$ & Sendangsari & Sendangrejo & Sendangarum & Sendangmulyo & Sendangagung \\
\hline Rendah-Rendah & 15 & 25 & 22 & 24 & 7 \\
Rendah-Sedang & 20 & 11 & 15 & 15 & 31 \\
Sedang-Rendah & 2 & 3 & 3 & 1 & 2 \\
Sedang-Sedang & 3 & 1 & 0 & 0 & 0 \\
\hline
\end{tabular}


[2]. Notopuro, Hardjito, 1999, Peran Waniita dalam Masa Pembangunan di Indonesia, Ghalia Indonesia, Jakarta

[3]. Sudarwati, Lina., 2003, Wanita dan Struktur Sosial, USUpress- Universitas Sumatra Utara

[4]. Peranan Wanita, Anak dan Remaja, dan Pemuda, www.bappenas.go.id

[5]. Baso, Zohra A, 2000, Langkah Perempuan, Yayasan Lembaga Konsemen, Sulawesi Selatan
[6]. Siregar, Mastauli., 2007, Keterlibatan Ibu Bekerja dalam perkembangan Pendidikan Anak, Jurnal Harmoni Sosial, USUpressUniversitas Sumatra Utara

[7]. www.repository.unhas.ac.id

[8]. Supriharyono, 2002, Intisari Materi Kuliah metodologi Penelitian, Program Pasca Sarjana Magister Teknik Sipil Universitas Diponegoro, Semarang 